\title{
ДЕЯКІ АСПЕКТИ ПРОЦЕДУРИ НАДАННЯ ПУБЛІЧНИХ ПОСЛУГ У СФЕРІ СПРАВЛЯННЯ ПОДАТКІВ
}

\author{
ЛАШКУН Анастасія Ігорівна - начальник управління супроводження \\ судових справ Східного міжрегіонального управління ДПС по роботі з великими \\ платниками податків
}

УДК 342.228+342.7

DOI 10.32782/NP.2021.4.19

Научная статья посвящена характеристике процедуры предоставления административных услуг в сбере взимания налогов и сборов. В Украине на сегодняшнее время процедуръ предоставления административнъгх услуг в сфере взимания налогов и сборов требует усовершенствования. Ведь в Законе Украинъ «Об административньх услугах» характеристика механизма прочедуры предоставления административных услуг в сбере взимания налогов и сборов содержит только бормальнъие аспекть и имеет отсълочнъий характер к другим нормативно-правовълм актам, что, в свою очередь, приводит к собственному и довольно противоположному толкованию норм субъектами публичной администрации.

По направлениям совершенствования процедурь предоставления административньгх услуг в сбере взимания налогов и сборов являются: разработка и принятие Закона Украинь «Об административньх процедурах»; размер оплать за видь электронньих услуг должнъ определяться исключительно в законах, а не в подзаконных нормативно-правовых актах; разработать и принять Закон Украинъи «Об административном сборе», в котором должно бъть унибицировано название плать за административнвие услуги; необходимо определить единъле размерь административньих сборов для всех видов административнъгх услуг.

Установлено стадии процедуры предоставления административнъгх услуг в сбере взимания налогов и сборов: 1) принятие документов и заявления, его регистрачия в установлен- ном в соответствии с Типовой инструкиии по делопроизводству в иентральньх органах исполнительной власти, Совету министров Автономной Республики Крыл, местнъхх органах исполнительной власти, утвержденной постановлением Кабинета Министров Украинъг от 30 ноября 2011 года № 1242; 2) проверка полноть, комплектности документов, достоверности предоставленнъхх сведений, может проводиться и путем осмотра и фотограбирования складских обгектов, прилегающей территории, проверки соответствия складских объектов сведениям, указанным в приложенных к заявлению о предоставлении разрешения документах. По результатам «бактической» проверки составляется акт. Срок проверки как документов, так и соответствия будущих объектов производства разрешительной деятельности является обшим и не должен превъпшать 10 рабочих дней дня регистрачии заявления; 3) принятие решения о предоставлении разрешения или отказе в вълдче разрешения, обормление соответствующего решения приказом, что происходит в срок не более 3 рабочих дней со дня составления акта; 4) регистрация объекта разрешительной деятельности в соответствующем Реестре; 5) направление заявителю выписки uз Pеecmpa.

Ключевъе слова: услуга, административная услуга, нормативно-правовой акт, правовое регулирование, процедура предоставления административньх услуг в сфере взимания налогов и сборов, стадии. 


\section{Цивільне, підприсмницьке, господарське та трудове право}

\section{Вступ}

Оновлення методологічних підходів до визначення предмета адміністративного права, а також засобів, що можуть бути використані органами публічної адміністрації для впорядкування і розвитку публічних правовідносин, впливу на фізичних і юридичних осіб, визнання в науці адміністративного права «людиноцентристської» концепції публічного управління [1, с. 4], запропонованої В. Б. Авер'яновим, зумовлює появу такого інституту, як адміністративна послуга. Запровадження цього інституту вимагає грунтовних досліджень організаційно-правових засад надання таких послуг органами публічної адміністрації, серед яких особливої уваги заслуговують органи, адміністративна діяльність яких пов'язана із постійною взаємодією із фізичними та юридичними особами.

Відповідно, вдосконалення процедури надання публічних послуг у сфері справляння податків необхідно розглядати як пріоритетний напрям модернізації діяльності органів ДФС, що дозволить: поперше, підвищити довіру населення до діяльності посадових осіб цього органу, по-друге, виконати вимоги Закону України «Про центральні органи виконавчої влади» 17.03.2011 № 3166-VI, у частині 2 статті 17 якого встановлено, що пріоритетним завданням центрального органу виконавчої влади, утвореного як служба, $є$ надання адміністративних послуг фізичним і юридичним особам.

Вивченню організаційно-правового механізму надання адміністративних послуг органами фіскальної служби повинне передувати визначення поняття «адміністративна послуга», що, на думку Д. В. Приймаченка, має як практичне, так і теоретичне значення [8, с. 7]. Необхідно зазначити, що у законодавстві адміністративну послугу визначено як результат здійснення владних повноважень [9], а в науковій літературі під послугою переважно мають на увазі саму діяльність $[20$, с. $120 ; 1$. с. 456], тобто обслуговування [8, с. 8].

Так, Г. М. Писаренко називає адміністративною послугою правовідносини, що виникають при реалізації суб’єктивних прав фізичної або юридичної особи (за їх заявою) у процесі публічно-владної діяльності адміністративного органу для отримання певного результату [7, с. 8]. Причому дослідниця робить акцент на виконанні обов'язків держави перед приватними особами, спрямованих на юридичне оформлення умов, необхідних для забезпечення належної реалізації ними своїх прав і охоронюваних законом інтересів. Такої думки дотримується і I.A. Мордвін, який, досліджуючи адміністративні послуги податкових органів [6], визначає їх як категорії адміністративного права, що породжує адміністративні правовідносини при реалізації суб'єктивних прав фізичної або юридичної особи (за їхньою заявою) процесі владної діяльності податкових органів України для отримання певного результату (набуття, зміни чи припинення прав та/ або обов'язків такої особи у сфері оподаткування відповідно до закону) [6, с. 8].

Д. Сухінін і Ю. Шаров розглядають адміністративні послуги як результат здійснення владних повноважень суб'єктом, що відповідно до закону забезпечує юридичне оформлення умов реалізації фізичними та юридичними особами прав, свобод і законних інтересів за їх заявою (видача дозволів (ліцензій), сертифікатів, посвідчень, проведення реєстрацій тощо) [23, с. 232]. В.М. Циндря, уточнюючи зміст адміністративних послуг щодо діяльності органів внутрішніх справ, також визначає їх як результат здійснення цими органами повноважень щодо юридичного оформлення реалізації фізичними та юридичними особами прав, свобод і законних інтересів за їх заявою (видача дозволів (ліцензій), сертифікатів, посвідчень, проведення реєстрації тощо). При цьому науковці акцентують увагу на такій ознаці послуги, як цінність для споживачів за межами органу внутрішніх справ та сприйняття ними як послуги $[22$, c. 15$]$.

К.А. Фуглевич пропонує визначати адміністративні процедури 3 надання адміністративних послуг як передбачений законодавством порядок дій уповноважених осіб органів публічної адміністрації щодо надання адміністративних послуг, 
а також фізичних і юридичних осіб щодо виконання умов їх отримання [21, с. 13]. Відповідно, дослідницею до суб'єктів адміністративних процедур включено отримувачів послуг - платників податків, що, на нашу думку, є не виправданим. Виконання правил і вимог дозвільної діяльності як на момент звернення за послугою, так і під час подальшого провадження відповідної діяльності, $\epsilon$ необхідною умовою отримання дозвільної адміністративної послуги, та користування їі результатом. Однак виконання названих вимог є швидше передумовою отримання послуги, ніж фактичними діями щодо іiі надання. Стосовно цього доцільно погодитися 3 висновками О. О. Сосновика, на думку якого правила видачі дозволів умовно можна розділити на умови (тобто сукупність усіх необхідних підстав для видачі дозволу - відповідність суб'єкта встановленим вимогам, мети відповідної діяльності, наявність технічних можливостей тощо) і порядок (процедуру видачі - оформлення необхідних документів, місце, строки прийняття рішення, його виконання тощо) [19, с. 112].

\section{Мета та задачі дослідження}

Метою статті висвітлення характеристики процедури надання публічних послуг у сфері справляння податків.

Для досягнення мети були поставлені такі задачі: охарактеризувати види процедури надання публічних послуг у сфері справляння податків; виокремити проблемні питання процедури надання публічних послуг у сфері справляння податків.

\section{Виклад основного змісту}

Відповідно до МК України [4], органи ДФС уповноважені надавати такі види дозволів на: відкриття та експлуатацію складу тимчасового зберігання, відкриття та експлуатацію митного складу, відкриття та експлуатацію вільної митної зони комерційного або сервісного типу, відкриття та експлуатацію магазину безмитної торгівлі, здійснення митно-брокерської діяльності.

Процедури надання кожної $з$ названих послуг передбачені окремими нормативни- ми актами Міністерства фінансів України, які пропонується розглянути 3 метою виявлення порядку дій посадових осіб органів ДФС під час надання адміністративних послуг, що дозволить визначити позитивні та негативні риси в організаційно-правовому забезпеченні такої діяльності.

Необхідно зауважити, що відповідно до вимог Міжнародної конвенції про спрощення і гармонізацію митних процедур [5], яка набула чинності в Україні 15.09.2011, МК України визначає уніфіковані вимоги до видачі дозволів у сфері державної митної справи, встановлені Главою 58 «Загальні положення щодо здійснення митними органами контролю за окремими видами діяльності підприємств» [3].

Отже, процедура надання публічних послуг у сфері справляння податків повинні відповідати таким законодавчим вимогам: 1) строк прийняття рішення про видачу дозволу і, відповідно, внесення відомостей до реєстру, або відмову у видачі дозволу не повинен перевищувати 20 робочих днів 3 дня надходження заяви про отримання послуги; 2) строк видачі витягу 3 реєстру становить три робочі дні 3 дня прийняття рішення про надання дозволу; 3) підставою для відмови у видачі дозволу є невиконання заявником вимог, встановлених для його отримання [4].

Власне процедури надання дозволів у сфері державної митної справи визначаються Міністерством фінансів України та закріплюються у відповідних підзаконних актах. Водночас до компетенції Міністерства фінансів України віднесено упорядкування: форм, порядку подання та розгляду заяв; вимог та правил провадження видів дозвільної діяльності; процедур надання, зупинення дії, анулювання дозволів; підстав, періодичності, форм, тривалості контролю за провадженням дозвільної діяльності.

Умови отримання дозволів стосуються переважно матеріально-технічного забезпечення дозвільної діяльності, у тому числі і безпеки (пожежної, санітарно-епідеміологічної тощо) та охорони об'єктів і місць їі провадження. Втім, характерною ознакою умов отримання дозволів як адміністратив- 


\section{Цивільне, підприсмницьке, господарське та трудове право}

них послуг органів ДФС України у галузі митної справи є встановлення вимог до забезпечення виконання посадовими особами митних органів контролю за дотриманням правил провадження відповідноӥ діяльності. Так, згідно з Положенням про склади тимчасового зберігання, затвердженим Наказом Міністерства фінансів України від 28.05.2012 № 613 (далі - Положення № 613), утримувач складу тимчасового зберігання повинен: забезпечити безперешкодний доступ посадових осіб органів ДФС до систем відеоспостереження, обладнати робочі місця для посадових осіб підрозділу митного оформлення, у тому числі канали і засоби зв'язку [13], Порядку подання та розгляду заяв і надання дозволу на провадження митної брокерської діяльності та контролю за нею, затвердженого Наказом Міністерства фінансів України від 04.08.2015 № 693 (далі - Порядок№ 693) [12].

Аналіз нормативних приписів, що регламентують надання дозволів у галузі митної справи органами ДФС, у тому числі Положення 613 [13], Порядку надання складським об'єктам статусу «митний склад» та позбавлення такого статусу, затвердженого Наказом Міністерства фінансів України 16.07.2012 № 835 [15] (далі Порядок №835), Наказу Міністерства фінансів України від 30.05.2012 № 633 «Про деякі питання відкриття та експлуатації вільної митної зони комерційного або сервісного типу» (далі - Наказ № 633) [14], Порядку подання та розгляду заяв, надання, зупинення дії, анулювання дозволів на відкриття та експлуатацію магазину безмитної торгівлі та форми заяви на відкриття та експлуатацію магазину безмитної торгівлі, затвердженого Наказом Міністерства фінансів України від 08.06.2012 № 692 (далі - Наказ № 692) [16] дозволяє виділити такі характері ознаки процедур надання відповідних послуг.

По-перше, наявність форми об'єктивації рішення про надання або відмову у наданні відповідного дозволу - наказ, видання якого є підставою для внесення відомостей до реєстрів; по-друге - поєднання дозвільних (видача наказу про надання дозволу) та ре- єстраційних дій (внесення відомостей про майбутній об'єкт провадження дозвільної діяльності до відповідних реєстрів); потретє - результатом надання адміністративної послуги виступає витяг з реєстру.

Виявлені особливості процедур надання дозволів органів ДФС вимагають окремих пояснень. Поєднання процедур надання дозволу на відкриття та експлуатацію об'єктів дозвільної діяльності та їх реєстрацію у відповідному реєстрі свідчить про впровадження принципу «єдиного вікна», який передбачає здійснення максимально можливої кількості процедурних дій, що провадяться суб'єктами надання адміністративних послуг, для надання адміністративної послуги без залучення суб'єктів звернення, які бажають ії отримати, у практичну діяльність органів ДФС, однак не підтверджує належності реєстраційних послуг до дозвільних адміністративних послуг.

Отже, в узагальненому вигляді процедура надання публічних послуг у сфері справляння податків складається 3 такої послідовності дій:

1) прийняття документів та заяви, пї реєстрація у встановленому відповідно до Типової інструкції з діловодства у центральних органах виконавчої влади, Раді міністрів Автономної Республіки Крим, місцевих органах виконавчої влади, затвердженої постановою Кабінету Міністрів України від 30 листопада 2011 року№ 1242 ;

2) перевірка повноти, комплектності документів, достовірності наданих відомостей, що може проводитися і шляхом огляду та фотографування складських об'єктів, прилеглої території, перевірки відповідності складських об'єктів відомостям, зазначеним у доданих до заяви про надання дозволу документах. За результатами «фактичної» перевірки складається акт. Строк перевірки як документів, так і відповідності майбутніх об'єктів провадження дозвільної діяльності є загальним та не повинен перевищувати 10 робочих днів 3 дня реєстрації заяви.

3) прийняття рішення про надання дозволу або відмову у видачі дозволу, оформ- 
лення відповідного рішення наказом, що відбувається у строк не більше 3 робочих днів 3 дня складання акта. Доцільно зазначити, що більшість із зазначених вище нормативних актів Міністерства фінансів України не містить підстав для відмови у наданні дозволу, лише Наказ № 633 визначає такими: ненадання заявником відомостей, передбачених формою заяви; надання заявником недостовірних відомостей у заяві та доданих до неї документах; неподання заявником документів, необхідних для отримання дозволу; ненадання фізичною особою - підприємцем, відповідно до Закону України 01.06.2010 № 2297-VI «Про захист персональних даних», згоди на обробку та поширення митницею, яка розглядає заяву, та ДФС України його персональних даних; невідповідності матеріально-технічної бази встановленим вимогам.

4) реєстрація об'єкта дозвільної діяльності у відповідному Реєстрі;

5) надсилання заявнику витягу з Реєстру.

\section{Висновки}

1. Запропоновано під процедурою надання публічних послуг у сфері справляння податків - це публічно-владна діяльність окремих служб, підрозділів чи органів ДФС (їх окремих посадових осіб) щодо визнання за умови відповідності встановленим вимогам за особою права здійснювати певні дії, провадити конкретний вид господарської діяльності, щодо яких законом встановлено заборону вчинення без спеціального уповноваження, шляхом видачі за заявою такої особи документа встановленого зразка (дозволу, ліцензії, свідоцтва).

2. Процедуру надання публічних послуг у сфері справляння податків доцільно поділити на видачу дозволів та надання ліцензій, що зумовлено як відмінностями правового регулювання процедур надання, так і сферами суспільного життя, де вони застосовуються.

3. Серед загальних проблем правового регулювання потрібно виокремити переважно підзаконне регулювання, всупереч вимогам Закону України 06.09.2012-
№ 5203-VI «Про адміністративні послуги», переліку та вимог до документів, необхідних для отримання дозвільних адміністративних послуг, що надаються органами ДФС, переліку підстав для відмови у наданні адміністративної послуги.

\section{Лiтepaтура}

1. Авер'янов В. Б. Адміністративне право. Академічний курс : підруч. : у 2 т. К. : Юрид. думка, 2005. Т. 2. Особлива частина. 624 с.

2. Авер'янов В.Оновлення доктринальних засад українського адміністративного права у світлі євроінтеграційних вимог. Юридична Украйна. 2010. № 3. С. 4-10.

3. Дубенко С. Д. Адміністративні послуги органів виконавчої влади: теоретичні підходи до вирішення практичних завдань (на допомогу слухачам системи підвищення кваліфікації державних службовців). К. : НАДУ, 2008. 44 с.

4. Митний кодекс України : Закон України: від 13.03.2012 № 4495-VI // Відомості Верховної Ради України (ВВР). - 2012. - № 44-45, № 46-47, № 48. - ст.552

5. Міжнародна конвенція про спрощення і гармонізацію митних процедур: від 18.05.1973. Офіційний вісник України від 23.09.2011. - 2011. - № 71 - ст. 727. --С. 244.

6. Мордвін I. А. Адміністративні послуги податкових органів України : дис.... канд. юрид. наук : 12.00.07. Х., 2013. 189 с.

7. Писаренко Г. М. Адміністративні послуги в Україні: організаційно-правові аспекти : автореф. дис. на здобуття наукового ступеня кандидата юридичних наук : спец. 12.00.07 - адміністративне право і процес; фінансове право; інформаційне право . Одеса, 2006. 20 с.

8. Приймаченко Д. В. Адміністративні послуги, що надають митні органи: стан i перспективи. Вісник Академї митної служби України.Серія «Право». 2010. № 2 (5).C. 6-12.

9. Про адміністративні послуги : Закон України: від 6 вересня 2012 року-

10. № 5203-VI [Електронний ресурс] Режим доступу : http://zakon4.rada.gov.ua/ laws/show/5203-17 


\section{Цивільне, підприсмницьке, господарське та трудове право}

11. Про впорядкування видачі суб'єктам підприємницької діяльності ліцензій на право оптової торгівлі спиртом етиловим і плодовим, алкогольними напоями та тютюновими виробами : Постанова Кабінету Міністрів України: від 31 березня 1999 року № 500 // Офіційний вісник України від 23.04.1999. - 1999.- С. 24.

12. Про державне регулювання виробництва і обігу спирту етилового, коньячного і плодового, алкогольних напоїв та тютюнових виробів : Закон України : від 19 грудня 1995 року № 481/95-ВР // Відомості Верховної Ради України (ВВР). - 1995. № 46. - ст. 345 .

13. Про діяльність митних брокерів : Наказ Міністерства фінансів: від 04.08.2015 № 693 // Офіційний вісник України від 18.09.2015. - 2015. - № 72. - с. 230. ст. 2394.

14. Про затвердження Положення про склади тимчасового зберігання : Наказ Міністерства фінансів України: від 28.05.2012 № 613 // Офіційний вісник України від 23.08.2012. - 2012. - № 62. C. $225 .-$ ст. 2552

15. Про затвердження Порядку відкриття та експлуатації вільної митної зони комерційного або сервісного типу : Наказ Міністерства фінансів України від 30.05.2012 № 633 // Офіційний вісник України. - 2012. - № 59. - С. 196. - ст. 2382.

16. Про затвердження Порядку надання складським об'єктам статусу «митний склад» та позбавлення такого статусу: Наказ Міністерства фінансів України: від 16.07.2012 № 835 // Офіційний вісник України від 20.08.2012. -2012. - № 61. С. 135. - ст. 2491.

17. Про затвердження Порядку подання та розгляду заяв, надання, зупинення дії, анулювання дозволів на відкриття та експлуатацію магазину безмитної торгівлі та форми Заяви на відкриття та експлуатацію магазину безмитної торгівлі : Наказ Міністерства фінансів України: від 08.06.2012 № 692. Офіційний вісник України від 27.07.2012. - 2012. - № 54. С. 139. - ст. 2184.

\section{АНОТАЦІЯ}

Наукова стаття присвячена характеристиці прочедури надання публічних послуг у сфері справляння податків. В Украӥні на съогоднішній час процедури надання публічних послуг у сфері справляння податків потребує удосконалення. Адже в Законі України «Про адміністративні послуги» характеристика механізму прощедури надання публічних послуг у сфері справляння податків містить тільки фбормальні аспекти та має відсильний характер щодо іниих нормативно-правових актів, що, у свою чергу, призводить до власного $i$ доволі протилежного тлумачення норм суб'єктами публічної адміністраиї.

Щодо напрямів удосконалення прощедури надання публічних послуг у сббері справляння податків $\epsilon:$ розроблення та прийняття Закону Украӥни «Про адміністративні прощедури»; розмір оплати за види електронних послуг мають визначатись лише у законах, а не у підзаконних нормативно-правових актах; розробити та прийняти Закон України «Про адміністративний збір», у якому має бути унібіковано назву плати за адміністративні послуги; необхідно визначити єдині розміри адміністративних зборів для всіх видів адміністративних послуг.

Встановлено стадї̈ прощедури надання публічних послуг у сбері справляння податків:1) прийняття документів та заяви, ї реєстрація у встановленому відповідно до Типової інструкий з діловодства у центральних органах виконавчої влади, Раді міністрів Автономной Республіки Крим, місцевих органах виконавчої влади, затвердженої постановою Кабінету Міністрів Украӥни від 30 листопада 2011 року№ 1242; 2) перевірка повноти, комплектності документів, достовірності наданих відомостей, що може проводитися $i$ шляхом огляду та фотографування складсъких об'єктів, прилеглої територіі, перевірки відповідності складсъких об'єктів відомостям, зазначеним у доданих до заяви про надання дозволу документах. 3 р результатами «бактичної» перевірки складається акт. Строк перевірки як документів, так $і$ відповідності майбутніх об'єктів провадження дозвільної діяльності є загальним та не повинен перевишувати 10 робочих днів дня реєстрачй заяви;3) прийняття рішення про надання дозволу або відмову у видачі дозволу, обормлення відповідного рішення наказом, що відбувається у строк не більше 3 робочих днів з дня складання акта;- 4) реєстрація об'єкта дозвільної діяльності у відповідному Реєстрі; 5) надсилання заявнику витягу з Реєстру.

Ключові слова: послуга, адміністративна послуга, нормативно-правовий акт, правове регулювання, прощедура надання публічних послуг у сбері справляння податків, стадї. 


SUMMARY
The scientific article is devoted to the
characteristics of the procedure of providing
administrative services in the field of taxation
and fees. In Ukraine, the procedure for providing
administrative services in the field of tax and
levying needs to be improved. After all, in the
Law of Ukraine "On Administrative Services",
the characterization of the mechanism of the
procedure of providing administrative services in
the field of taxation and collection contains only
formal aspects and is reflective of other normative
legal acts, which, in turn, leads to its own and
quite opposite interpretation of norms. subjects of
public administration.
Regarding the directions of improvement
of the procedure of providing administrative
services in the field of taxation and collection are:
development and adoption of the Law of Ukraine
"On Administrative Procedures"; the amount of
payment for types of electronic services should be
determined solely by law, not by-laws; to develop
and adopt the Law of Ukraine "On Administrative
Fee", which should unify the name of the fee for
administrative services; it is necessary to define
uniform rates of administrative fees for all types
of administrative services.
The stages of the procedure of providing
administrative services in the field of taxes and
fees are established: 1) acceptance of documents

and applications, its registration in the established in accordance with the Model Instruction in the Central Executive Bodies, the Council of Ministers of the Autonomous Republic of Crimea, local executive bodies, approved by resolution Ministers of Ukraine dated November 30, 2011 No. 1242; 2) check the completeness, completeness of the documents, the accuracy of the information provided, which can be carried out by inspecting and photographing the storage facilities, the surrounding area, checking the compliance of the storage facilities with the information specified in the documents attached to the application for authorization. According to the results of the "actual" inspection, an act is drawn up. The term of verification of both documents and compliance of future objects of conducting permitting activity is general and should not exceed 10 working days on the day of registration of the application; 3) making a decision on granting a permit or refusing to grant a permit, issuing a relevant decision by an order occurring within no more than 3 working days from the date of drafting the act; 4) registration of the object of permitting activity in the respective Register; 5) sending to the applicant an extract from the Register.

Key words: service, administrative service, legal act, legal regulation, procedure of providing administrative services in the field of taxation and fees, stages. 